\title{
EVALUASI KESENJANGAN PENGGUNAAN ALAT BANTU SELEKSI KOLEKSI TERHADAP RELEVANSI KEBUTUHAN PEMUSTAKA PERPUSTAKAAN STIKES 'AISYIYAH YOGYAKARTA
}

\author{
Irkhamiyati \\ Pustakawan STIKES ‘Aisyiyah Yogyakarta \\ irkhamir@yahoo.com
}

Informasi berkembang menjadi suatu kebutuhan dalam pengembangan ilmu dan menjadi sumber yang digunakan dalam menjawab pertanyaan yang timbul pada masyarakat luas. $\mathrm{Hal}$ ini menjadi tantangan perpustakaan dalam menyediakan informasi bagi pemustakanya. Salah satunya bisa dilakukan dengan menggunakan alat bantu seleksi untuk menyediakan koleksi yang relevan dengan kebutuhan pemustaka. Tersedia banyak alat bantu untuk pengadaan koleksi perpustakaan, namun belum semua perpustakaan memanfaatkannya. Kondisi demikian bisa terjadi di Perpustakaan STIKES 'Aisyiyah Yogyakarta, sehingga menarik untuk dievaluasi menggunakan observasi dan wawancara. Hasil evaluasi menunjukkan adanya kesenjangan penggunaan alat bantu seleksi koleksi publisher announcement dibanding dengan alat seleksi lainnya. Dengan demikian perlu dicarikan cara mengatasi kesenjangan penggunaan alat bantu seleksi tersebut, agar tidak berdampak terhadap relevansi koleksi yang dibutuhkan pemustakanya.

Kata kunci: evaluasi, kesenjangan, alat bantu seleksi koleksi, relevansi, pemustaka.

\section{Pendahuluan}

Informasi kini berkembang menjadi suatu kebutuhan dalam pengembangan ilmu dan menjadi sumber yang digunakan dalam menjawab pertanyaan yang timbul pada masyarakat luas. Perpustakaan suatu institusi yang mengelola berbagai jenis informasi, tentunya harus berkembang seiring dengan perkembangan diatas. Informasi yang disediakan oleh perpustakaan, bisa berupa koleksi fisik, audio visual atau dalam bentuk data base elektronik. Berbagai sumber informasi tersebut dinamakan dengan koleksi perpustakaan.

Koleksi perpustakaan merupakan objek utama atau dasar dari pengadaan bahan pustaka di perpustakaan. Perpustakaan perguruan tinggi sebagai media penyedia informasi sebaiknya memiliki bahan pustaka yang banyak dan beraneka ragam serta relevan dengan kebutuhan pemustakanya. Koleksi perpustakaan yang bermutu akan mewujudkan perpustakaan yang bermutu pula. Kegiatan pengadaan koleksi dan berbagai sumber informasi di perpustakaan, tidak bisa lepas dari proses seleksi terhadap koleksi dan berbagai sumber informasi yang akan diadakan. Dalam proses seleksi, tidak bisa lepas dari alat atau sarana atau sumber daya yang digunakannya. Untuk dapat mewujudkan tujuan pengadaan koleksi yaitu menyediakan koleksi yang sesuai/ relevan dengan kebutuhan pengguna, menuntut kemampuan pustakawan dalam memilih bahan pustaka harus lebih maksimal. Oleh karena itu diperlukan alat bantu seleksi dalam pemilihan koleksi perpustakaan.

Tersedia banyak alat bantu untuk pengadaan koleksi perpustakaan, namun belum semua perpustakaan memanfaatkan sarana tersebut sebagai alat seleksi koleksi. Ada sebagian perpustakaan, dalam pengadaan koleksi hanya asal mengadakan, sekedar menghabiskan anggaran, sehingga tergantung pada penawaran toko buku dan penerbit tertentu saja, tanpa menggunakan alat bantu seleksi. Keadaan demikian bisa terjadi pula di Perpustakaan STIKES 'Aisyiyah Yogyakarta. Permasalahan utama yang ada di Perpustakaan STIKES 'Aisyiyah Yogyakarta adalah adanya kesenjangan penggunaan alat bantu seleksi 
koleksi. Kesenjangan tersebut terlihat dengan mendominasinya penggunaan salah satu alat bantu seleksi koleksi, dibanding dengan alat bantu seleksi lainnya dalam pengadaan koleksi di Perpustakaan STIKES 'Aisyiyah Yogyakarta. Hal itu akan berdampak terhadap terpenuhi atau tidaknya kebutuhan informasi yang sesuai/ relevan bagi pemustaka perpustakaan.

\section{Rumusan Masalah}

Berdasarkanuraiandiatas, makarumusan masalah dalam tulisan ini adalah sebagai berikut.

1. Alat bantu seleksi apa sajakah yang digunakan dalam pengadaan koleksi di Perpustakaan STIKES 'Aisyiyah Yogyakarta?

2. Apakah alasan yang menyebabkan penggunaan atau tidak digunakannya jenis alat bantu seleksi tertentu dalam pengadaan koleksi di Perpustakaan STIKES 'Aisyiyah Yogyakarta?

3. Apakah dampak dari kesenjangan penggunaan alat bantu seleksi terhadap relevansi kebutuhan pemustaka Perpustakaan STIKES 'Aisyiyah Yogyakarta?

4. Bagaimanakah cara mengatasi kesenjangan penggunaan alat bantu seleksi di Perpustakaan STIKES 'Aisyiyah Yogyakarta?

\section{Tujuan}

1. Untuk mengevaluasi alat bantu seleksi apa saja yang digunakan dalam pengadaan koleksi di Perpustakaan STIKES 'Aisyiyah Yogyakarta.

2. Untukmengetahuialasanyang menyebabkan penggunaan atau tidak digunakannya jenis alat bantu seleksi tertentu dalam pengadaan koleksi di Perpustakaan STIKES 'Aisyiyah Yogyakarta.

3. Untuk mengetahui dampak dari kesenjangan penggunaan alat bantu seleksi terhadap relevansi kebutuhan pemustaka Perpustakaan STIKES 'Aisyiyah Yogyakarta.

4. Untuk memberikan solusi agar tidak terjadi kesenjangan penggunaan alat bantu seleksi di Perpustakaan STIKES 'Aisyiyah Yogyakarta.

\section{Manajemen Koleksi}

Sebuah perpustakaan dan pusat nformasi, menjalankan dua konsteks lingkungan, yaitu lingkungan internal dan eksternal, yang keduanya berpengaruh terhadap pengelolaan manajemen perpustakaan (Bryson, 1990). Manajemen koleksi/collection management termasuk jenis kegiatan di perpustakaan yang menjalankan dua konsteks ingkungan, baik internal maupun eksternal di atas. Collection management merupakan manajemen sistematis atas perencanaan, komposisi pendanaan, evaluasi dan penggunaan koleksi sepanjang waktu guna memenuhi tujuan dan sasaran spesifik institusi perpustakaan untuk memenuhi kebutuhan pemustaka. Kegiatan yang tercakup dalam pengembangan koleksi antaralain adalah: kebijakan pengembangan koleksi, pemilihan, pengadaan, penyiangan, dan evaluasi pendayagunaan koleksi. Pengembangan koleksi mencakup: seleksi koleksi, kebijakan pengembangan koleksi, perawatan koleksi (termasuk penyiangan, penggudangan, preservasi, dan pembatalan koleksi), anggaran dan biaya, hubungan koleksi dengan pemustaka, evaluasi koleksi, dan rencana kerja sama, serta resource sharing (Johnson, 2009).

\section{Pengembangan Koleksi dan Kebijakan Pengembangan Koleksi}

Informasi yang disediakan oleh perpustakaan harus direncanakan dengan lebih baik,yangmeliputitahap datayangmemuatsumber informasi yang akan diadakan, pelaksanaan pengadaannya, staff yang menjalankannya, dan kebutuhan pemustakapemustaka yang tercukupi akan informasi perpustakaan (Stueart, 1993). Salah satu cara untuk dapat merealisasikan hal tersebut dapat dilakukan dalam kegiatan pengembangan koleksi perpustakaan. Pengembangan koleksi dan kebijakan pengembangan koleksi merupakan bagian dari manajemen koleksi/collection management. Pengembangan koleksi (collection development) dimaksudkan untuk membina sebaik-baiknya sesuai dengan kondisi perpustakaan dan masyarakat yang dilayani (Qalyubi, 2003).

Kegiatan pengembangan koleksi merupakan proses untuk memastikan bahwa kebutuhan informasi para pemustaka perpustakaan akan terpenuhi secara tepat waktu dan tepat guna. Lebih lanjut dijelaskan bahwa dalam pengembangan koleksi tidak 
hanya mencakup pengadaan koleksi saja, namun juga menyangkut rumusan kebijakan dalam memilih dan menentukan koleksi yang akan diadakan, serta metode-metode apa saja yang akan dilakukan (Qalyubi, 2003). Rumusan kebijakan dalam pengembangan koleksi sering disebut dengan kebijakan pengembangan koleksi/ collection development policies.

\section{Kebijakan pengembangan koleksi/} collection development policies adalah bagian tugas dari manajemen koleksi. Prinsip pembinaan koleksi menggambarkan tujuan dan isi koleksi dalam pengertian yang relevan dengan sasaran luar (termasuk pemustaka dan penyandang dana) dan sasaran intern (staf). Kebijakan pengembangan koleksi agar dapat berjalan sesuai dengan fungsinya, maka harus dibuat secara tertulis. Kebijakan pengembangan koleksi tertulis merupakan alat/sarana untuk mengarahkan segala aktivitas yang berkaitan dengan perencanaan, pendanaan, pemilihan, dan pengadaan bahan pustaka (Qalyubi, 2003). Hal-hal yang tercakup di dalamnya antara lain.

a. Siapa yang bertanggung jawab dalam pengembangan koleksi dan siapa yang diberi wewenang.

b. Metode pemilihan dan alat bantu seleksi.

c. Rincian spesifikasi koleksi yang akan diadakan.

d. Komposisi koleksi yang dikembangkan.

e. Bahasa.

f. Cara perolehan koleksi.

g. Kerja sama antar perpustakaan untuk pengembangan koleksi.

h. Kriteria dan tata cara penyiangan.

i. Kebijakan terhadap koleksi yang disensor , dll.

Kebijakan pengembangan koleksi sebagai pedoman agar tujuan pengembangan koleksi untuk menyediakan koleksi sesuai dengan kebutuhan pemustaka dapat terarah. Kesalahpahaman yang umum terjadi adalah bahwa bagian akuisisi menentukan dan memutuskan bahan pustaka apa yang akan diadakan, tanpa melibatkan unsur lainnya (Evans, 2011). Keputusan mengenai apa yang harus ditambahkan dalam koleksi sebenarnya melibatkan bagian lain seperti staf, pimpinan, dan pemustaka, agar koleksi yang diadakan lebih berdaya guna.
Agar proses seleksi koleksi lebih berkualitas, maka perpustakaan perlu mencantumkan berbagai alat seleksi koleksi dalam kebijakan tertulis pengembangan koleksinya. Sarana atau alat yang digunakan dalam proses seleksi koleksi sering disebut dengan alat bantu seleksi.

\section{Alat Bantu Seleksi}

Tidak semua perpustakaan menggunakan berbagai jenis alat bantu seleksi dalam pengembangan koleksinya. Menurut Evans (Juliyanti, 2002), alat bantu seleksi akan membantu pustakawan untuk menentukan apakah suatu bahan pustaka diseleksi (akan diusahakan pengadaannya melalui pembelian atau melalui cara lain). Alat bantu seleksi sangat banyak manfaatnya dalam kegiatan seleksi koleksi, karena berisi informasi yang membantu dalam pengambilan keputusan untuk mengadakan koleksi perpustakaan. Melalui alat bantu ini, perpustakaan akan mengetahui koleksi apa saja yang akan diadakan, bagaimana isinya, berapa harganya, bagaimana cara memperolehnya, dan lain-lain.

Alat bantu seleksi ada yang hanya menyajikan informasi singkat saja, seperti deskripsi judul, pengarang, penerbit, tahun, dan harga. Ada juga alat bantu seleksi yang memeberikan informasi lebih mendetail, selain deskripsi seperti tersebut di atas, juga ada tinjauan/review singkat dari koleksi yang ditawarkan kepada perpustakaan. Ada beberapa alat bantu seleksi untuk pengembangan koleksi perpustakaan sebagai berikut.

1. Pada perpustakaan perguruan tinggi sebaiknya pengadaan koleksi yang tepat adalah memilih koleksi perpustakaan yang mengikuti arah perkembangan ilmu pengetahuan dan teknologi, sehingga pengguna di perpustakaan ini mendapatkan informasi yang sesuai dengan perkembangan zaman di bidang pendidikan dan pengetahuan umum. Dengan demikian koleksi yang disediakan perpustakaan sesuai dengan kebutuhan. Alat bantu yang bisa digunakan untuk memilih bahan pustaka perpustakaan yaitu (Depdiknas, 2004): 
a. Silabus mata kuliah

Daftar silabus tiap mata kuliah, bisa dijadikan alat seleksi, sebab dalam setiap silabus mencantumkan daftar pustaka yang digunakan dalam mata kuliah yang bersangkutan.

b. Bibliografi

Bibliografi merupakan daftar koleksi, baik yang dibuat oleh perpustakaan, seperti perpustakaan daerah dan perpustakaan nasional, atau disusun oleh penerbit dan toko buku/agen.

c. Pangkalan data perpustakaan lain

Pangkalan data perpustakaan lain yang bisa diakses, juga bisa digunakan sebagai alat seleksi koleksi.

d. Sumber-sumber dari internet.

Sumber-sumber lain yang bisa diperoleh dari internet yang berhubungan dengan sumber koleksi dan sumber informasi sangat banyak. Hal ini bisa menjadi alat seleksi yang mudah dan cepat.

e. Tinjauan dan resensi buku.

Tinjauan yang ditulis baik berupa resensi buku yang diterbitkan oleh media massa ataupun review di internet sangat memungkinkan sebagai alat koleksi yang sangat membantu bagi perpustakaan dalam pengembangan koleksi.

2. Alat seleksi dan sumber daya dalam seleksi koleksi perpustakaan yang lain sebagai berikut (Johnson, 2009).

a. Bibibliografi.

Daftar bibliografi juga bisa dikeluarkan oleh perpustakaan tertentu, seperti Bibliografi yang disusun oleh Perpustakaan Daerah dan Perpustakaan Nasional, oleh penerbit, Asosiasi profesi, dan penerbit komersial. Alat seleksi dari bibliografi ini juga bisa berupa indeks dan direktori bidang tertentu.

b. Review (timbangan atau bedah buku di majalah dan surat kabar)

c. Publisher announcement.

Publisher announcement atau pem- beritahuan dari penerbit, biasanya berupa: brosur yang memuat daftar judul buku yang diterbitkan, advertisment/ penawaran dengan mengiklankan juduljudul tersebut yang dilengkapi dengan detail data, seperti: judul, pengarang, tahun terbit, ISBN, harga, dll. Selain itu berupa katalog dari penerbit, baik yang tercetak maupun berbentuk elektronik.

d. Review/approval copies, berupa review isi koleksi yang disertai dengan contoh koleksinya atau hanya salinannya.

e. Pameran buku dan toko buku.

f. Web-based tool/sarana seleksi berbasiskan internet memberikan beberapa pendekatan untuk mencari yang baru dan lebih relevan melalui internet.Pustakawan dapat menemukan rincian data tentang: agen yang menawarkan daftar judul koleksi yang masih beredar di pasaran/out of print, informasi penerbit, dan toko online, serta katalog yang mencakup semua format koleksi. Contohnya seperti: Amazon. com adalah salah satu agen online, yang lebih akrab dan berguna untuk pencarian berbasis subjek, ulasan, dan pengiriman item secara cepat. Penerbit sering menyediakan daftar isi dan bab sampel baru buku di situs Web mereka. Untuk penerbit dalam negeri seperti: Gramedia. com, Togamas.co.id, Erlangga.com, dan lain-lain.

\section{g. In-house information.}

Permintaan pinjaman antar perpustakaan bisa membantu sebagai alat seleksi. Permintaan berulang dari pengguna untuk artikel dari jurnal tertentu juga menunjukkan bahwa jurnal tersebut harus ditambahkan sebagai koleksi perpustakaan. Hal yang sama berlaku untuk permintaan untuk judul buku tertentu. Seringnya koleksi dipinjam atau panjangnya daftar tunggu yang untuk meminjam koleksi buku, memberikan bukti bahwa bahwa hal itu sebagai sarana yang harus dipertimbangkan untuk duplikasi atau penambahan koleksi. 
Relevansi

\section{Kebutuhan}

Perpustakaan

Pengertian relevansi di sini adalah informasi atau dokumen yang tersedia sesuai dengan kebutuhan pengguna. Hal ini diperkuat oleh pendapat yang menyatakan bahwa "dokumen yang relevan adalah dokumendokumen yang sedang dibutuhkan" (Purnomo, 2006). Dari uraian di atas dapat dikatakan bahwa relevansi merupakan kesesuaian dokumen-dokumen yang diperoleh dari perpustakaan atau sumber informasi lainnya, sehingga dapat memenuhi kebutuhan informasi pengguna dalam menggunakan perpustakaan.

Pendapat lain tentang relevansi menurut Siregar dalam (Rambe, 2010), maksud dari relevansi atau kesesuaian bahan perpustakaan adalah, "Perpustakaan hendaknya mengusahakan agar bahan perpustakaan relevansi dengan fungsi dan tujuan perpustakaan serta tujuan lembaga induknya". Berdasarkan pendapat di atas bisa disimpulkan bahwa relevansi bahan pustaka merupakan suatu tolak ukur bagi penelusur informasi untuk mengetahui apakah informasi yang dimiliki perpustakaan sesuai dengan kebutuhan pengguna, fungsi dan tujuan perpustakaan dan lembaga induknya.

\section{Evaluasi Kesenjangan Penggunaan Alat Bantu Seleksi Koleksi di Perpustakaan STIKES 'Aisyiyah Yogyakarta}

Secara harafiah kata evaluasi berasal dari bahasa Inggris evaluation yang berarti penilaian atau penaksiran (Echols, 1996). Sedangkan menurut (Arikunto, 1987) penilaian sama artinya dengan evaluation, yang dalam Bahasa Indonesia diartikan dengan evaluasi, yang berarti menilai (tetapi dilakukan dengan mengukur terlebih dahulu). Mengevaluasi tidak lain adalah memperoleh data.

Evaluasi yang dilakukan terhadap penggunaan alat bantu seleksi koleksi di Perpustakaan STIKES 'Aisyiyah Yogyakarta dengan cara observasi langsung dan wawancara. Teori yang digunakan untuk mengevaluai dengan menggabungkan dua pendapat (Depdiknas RI dan Johson) di atas. Hasil observasi menghasilkan temuan beberapa contoh alat seleksi yang digunakan dalam seleksi oleh Perpustakaan STIKES 'Aisyiyah Yogyakarta, seperti: brosur penawaran dari penerbit dan agen, katalog buku, email penawaran, dll. Sedangkan hasil wawancara untuk mengevaluai alat seleksi yang digunakan dan faktor-faktor yang menyebabkan penggunaan atau tidak digunakannya jenis alat bantu seleksi tertentu dalam pengadaan koleksi di Perpustakaan STIKES 'Aisyiyah Yogyakarta, dan menemukan kesenjangan penggunaan alat seleksi koleksi. Hasilnya dapat dilihat dalam tabel di bawah ini.

Evaluasi Kesenjangan Penggunaan Alat Bantu Seleksi Koleksi di Perpustakaan STIKES ‘Aisyiyah Yogyakarta

\begin{tabular}{|c|c|c|c|c|}
\hline No & $\begin{array}{c}\text { Jenis Alat } \\
\text { Bantu } \\
\text { Seleksi }\end{array}$ & $\begin{array}{c}\text { Diguna } \\
\text { kan }\end{array}$ & $\begin{array}{c}\text { Tidak } \\
\text { Diguna } \\
\text { kan }\end{array}$ & \\
\hline I & $\begin{array}{l}\text { Depdiknas } \\
\text { RI, } 2004\end{array}$ & & & \\
\hline 1 & $\begin{array}{l}\text { Silabus } \\
\text { mata kuliah }\end{array}$ & & & $\begin{array}{l}\text { Alat seleksi ini belum digunakan: } \\
\text { a. Tidak semua silabus menuliskan } \\
\text { daftar pustaka yang digunakan } \\
\text { dalam mata kuliah. Biasanya hal ini } \\
\text { dilakukan oleh dosen dari luar. } \\
\text { b. Kurangnya inasiatif } \\
\text { dari perpustakaan untuk } \\
\text { mengumpulkan silabus semua } \\
\text { mata kuliah agar bisa digunakan } \\
\text { sebagai alat bantu seleksi. } \\
\text { c. Terkadang kejadiannya } \\
\text { sebaliknya, dosen yang bertanya } \\
\text { sumber pustaka yang ada di } \\
\text { perpustakaan apa saja yang bisa } \\
\text { digunakan untuk mata kuliah } \\
\text { tersebut. }\end{array}$ \\
\hline 2 & Bibliografi & & & $\begin{array}{l}\text { Alat seleksi ini belum digunakan: } \\
\text { perpustakaan tidak pernah } \\
\text { menerima daftar bibliografi, baik } \\
\text { dari perpustakaan daerah maupun } \\
\text { dari perpustakaan nasional. } \\
\text { Beberapa penerbit kadang } \\
\text { memberikan katalog penerbit. }\end{array}$ \\
\hline 3 & $\begin{array}{l}\text { Pangkalan } \\
\text { data } \\
\text { perpusta } \\
\text { kaan lain }\end{array}$ & & & $\begin{array}{l}\text { Alat ini sering digunakan: } \\
\text { a. Ada kesulitan bagi perpustakaan } \\
\text { untuk mencari sumber informasi } \\
\text { secara langsung. } \\
\text { b. Mahalnya biaya untuk } \\
\text { memperoleh sumber informasi } \\
\text { tersebut. } \\
\text { Misalnya: } \\
\text { a. Untuk mengakses e-resources, } \\
\text { yang sulit dan mahal. Maka } \\
\text { perpustakaan menggunakan } \\
\text { pangkaan data Perpustakaan } \\
\text { Nasional untuk mengaksesnya. } \\
\text { b. Membantu pemustaka untuk } \\
\text { mendapatkan sumber informasi } \\
\text { ke website perpustakaan lain yang } \\
\text { punya subjek relevan dengan } \\
\text { kebutuhan pemustaka, seperti } \\
\text { melalui Intitusional Repository- } \\
\text { nya USU, Undip, Unnes, website } \\
\text { lontar.ui.ac.id, portal Garuda, dan } \\
\text { lain-lain. }\end{array}$ \\
\hline 4 & $\begin{array}{l}\text { Su m b e } r \text { - } \\
\text { sumber dari } \\
\text { internet }\end{array}$ & & & $\begin{array}{l}\text { Alat ini sering digunakan: } \\
\text { Internet menyajikan banyak } \\
\text { sumber informasi yang berguna } \\
\text { untuk perpustakaan. Oleh karena } \\
\text { itu banyak sumber di internet } \\
\text { dijadikan alat seleksi. } \\
\text { Contohnya: ketika perpustakaan } \\
\text { mencari sumber dari luar negeri, } \\
\text { sering mencari melalui: libgen.info, } \\
\text { 4shared.com, bookfree.com, dan } \\
\text { lain-lain. }\end{array}$ \\
\hline 5 & $\begin{array}{l}\text { Tinja u a n } \\
\text { dan resensi } \\
\text { buku }\end{array}$ & & $\sqrt{ }$ & $\begin{array}{l}\text { Alat bantu ini jarang digunakan } \\
\text { perpustakaan sebab tidak banyak } \\
\text { subyek kesehatan yang diresensi/ } \\
\text { dibedah di media yang berbahasa } \\
\text { Indonesia. }\end{array}$ \\
\hline II & $\begin{array}{l}\text { Pendapat } \\
\text { Johson, } \\
2009\end{array}$ & & & \\
\hline
\end{tabular}




\begin{tabular}{|c|c|c|c|c|}
\hline No & $\begin{array}{c}\text { Jenis Alat } \\
\text { Bantu } \\
\text { Seleksi }\end{array}$ & $\begin{array}{c}\text { Diguna } \\
\text { kan }\end{array}$ & $\begin{array}{c}\text { Tidak } \\
\text { Diguna } \\
\text { kan }\end{array}$ & \\
\hline 1 & Bibliography & & & $\begin{array}{l}\text { Alat seleksi ini belum digunakan, } \\
\text { perpustakaan tidak pernah } \\
\text { menerima daftar bibliografi, baik } \\
\text { dari perpustakaan daerah maupun } \\
\text { dari Perpustakaan Nasional. Kalau } \\
\text { ada dari penerbit tidak berupa } \\
\text { bibliografi. Indeks dan direktori } \\
\text { bidang tertentu juga tidak pernah } \\
\text { didapatkan oleh perpustakaan. }\end{array}$ \\
\hline 2 & $\begin{array}{l}\text { Publisher } \\
\text { announce- } \\
\text { ment }\end{array}$ & & & $\begin{array}{l}\text { Pemberitahuan dari penerbit } \\
\text { sering atau sebagian besar alat } \\
\text { seleksi yang digunakan memang } \\
\text { berupa publisher announcement: } \\
\text { a. Faktor kemudahan: penerbit } \\
\text { atau agen sering memberikan } \\
\text { brosur, daftar penawaran, dan } \\
\text { katalog buku yang memuat daftar } \\
\text { judul yang ditawarkan, dilengkapi } \\
\text { dengan data bibliografi seperti: } \\
\text { judul, pengarang, tahun terbit, } \\
\text { ISBN, harga, dan lain-lain. } \\
\text { b. Katalog penerbit yang tercetak } \\
\text { biasanya diantarkan oleh sales } \\
\text { marketing dari penerbit dan agen, } \\
\text { contohnya dari Penerbit Salemba } \\
\text { Medika, CV Sagung Seto, Toko } \\
\text { Buku Toga Mas, Toko Buku } \\
\text { Gramedia, Toko Buku Graha Ilmu, } \\
\text { Penerbit Bumi Aksara, Toko Buku } \\
\text { Social Agensi, Penerbit Nuha } \\
\text { Medika, dan lain-lain. } \\
\text { c. Sedangkan katalog yang } \\
\text { berbentuk elektronik bisa diperoleh } \\
\text { melalui email dan jejaring sosial, } \\
\text { seperti face book. Contohnya } \\
\text { dari CV Spektra, CV Fenros, } \\
\text { Galang Publisher, Penerbit Suara } \\
\text { Muhammadiyah, dan Trans Info } \\
\text { Media Jakarta. }\end{array}$ \\
\hline 3 & $\begin{array}{l}R \text { e } v \text { i e w } \\
\text { (timbangan } \\
\text { atau bedah } \\
\text { buku di } \\
\text { majalah dan } \\
\text { surat kabar) }\end{array}$ & & $\sqrt{ }$ & $\begin{array}{l}\text { Alat bantu ini jarang digunakan } \\
\text { sebab tidak banyak subyek } \\
\text { kesehatan yang diresensi// } \\
\text { dibedah di media yang berbahasa } \\
\text { Indonesia. }\end{array}$ \\
\hline 4 & $\begin{array}{l}R \text { eview } \\
\text { approval } \\
\text { copies }\end{array}$ & & & $\begin{array}{l}\text { Review yang disertai Approval } \\
\text { copies /salinan kopi/sample buku } \\
\text { sering didaptakan dari penerbit } \\
\text { Erlangga dan EGC, sehinga } \\
\text { sangat efektif sebagai alat seleksi. }\end{array}$ \\
\hline 5 & $\begin{array}{l}\text { P a m e ra n } \\
\text { buku dan } \\
\text { toko buku }\end{array}$ & & & 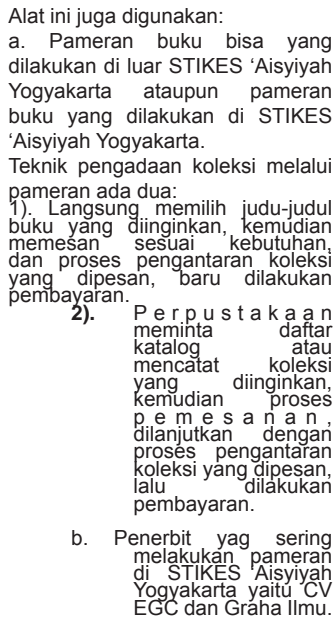 \\
\hline 6 & $\begin{array}{l}\text { Web-based } \\
\text { tool }\end{array}$ & & $\sqrt{ }$ & $\begin{array}{l}\text { Alat ini jarang digunakan padahal } \\
\text { cepat dan mudah mendapatkan } \\
\text { iformasinya. } \\
\text { Contohnya: dengan masuk di } \\
\text { erlangga.com, gramedia.com, } \\
\text { togamas.co.id, amazon.com, dan } \\
\text { lain-lain. }\end{array}$ \\
\hline
\end{tabular}

\begin{tabular}{|c|c|c|l|l|}
\hline No & $\begin{array}{c}\text { Jenis Alat } \\
\text { Bantu } \\
\text { Seleksi }\end{array}$ & $\begin{array}{c}\text { Diguna } \\
\text { kan }\end{array}$ & $\begin{array}{c}\text { Tidak } \\
\text { Diguna } \\
\text { kan }\end{array}$ & \\
\hline 7 & $\begin{array}{l}\text { In-house } \\
\text { information }\end{array}$ & & & $\begin{array}{l}\text { Alat ini juga digunakan: } \\
\text { Sesuai dengan tujuan } \\
\text { pengembangan koleksi adalah } \\
\text { untuk memenuhi kebutuhan } \\
\text { pemustaka, sebab permintaan } \\
\text { pengguna terhadap artikel tertentu } \\
\text { dari jurnal, permintaan judul dan } \\
\text { subjek buku termasuk alat seleksi } \\
\text { yang efektif. Apalagi jika koleksi } \\
\text { yang diusulkan berasal dari pihak } \\
\text { dosen, akan lebih tepat sasaran } \\
\text { dan maksimal pemanfaatannya. }\end{array}$ \\
\hline
\end{tabular}

Dampak Kesenjangan Penggunaan Alat Bantu Seleksi terhadap Relevansi Kebutuhan Pemustaka Perpustakaan STIKES 'Aisyiyah Yogyakarta

Tabel di atas menunjukkan bahwa alat bantu seleksi yang digunakan dalam pengadaan koleksi di Perpustakaan STIKES 'Aisyiyah Yogyakarta sudah bervariasi. Namun sayangnya, tabel di atas menunjukkan adanya kesenjangan (jarak yang sangat jauh penggunaan antar alat bantu seleksi). Hal itu terlihat dengan paling sering digunakannya publisher announcement sebagai alat bantu seleksi pengadaan koleksi di Perpustakaan STIKES 'Aisyiyah. Alat bantu seleksi berupa bibliografi, silabus mata kuliah, dan timbangan buku, terlihat tidak pernah digunakan dalam pengadaan koleksi. Kesenjangan ini akan berdampak terhadap relevansi kebutuhan pemustaka perpustakaan.

Penilaian relevansi sangat peting dalam mencari informasi atau dokumen yang dibutuhkan pemustaka sehingga perpustakaan harus menyediakan bahan perpustakaan yang optimal bagi pengunjung perpustakaan. Dua alat bantu seleksi yang tidak pernah digunakan adalah bibliografi dan silabus mata kuliah mempunyai dampak yang berbeda. Bibliografi dan timbangan buku yang tidak digunakan sebagai alat bantu seleksi, tidak begitu berdampak terhadap relevansi kebutuhan pemustaka di Perpustakaan STIKES 'Aisyiyah Yogyakarta. Akan tetapi, tidak digunakannya silabus sebagai alat bantu seleksi sangat disayangkan, sebab hal ini akan berdampak terhadap relevansi kebutuhan pemustaka di Perpustakaan STIKES 'Aisyiyah Yogyakarta. Beberapa dampak tersebut antara lain sebagai berikut:

1. Koleksi perpustakaan yang selama ini diadakan, dipertanyakan apakah sudah sesuai/relevan dengan kebutuhan 
Evaluasi Kesenjangan Penggunaan Alat Bantu ... (Irkhamiyati)

pemustaka, terlebih dalam rangka mendorong kegiatan belajar mengajar. Setiap mata kuliah akan dilengkapi dengan silabus, yang menuliskan sumber referensi atau daftar pustaka yang digunakan dalam perkuliahan. Begitu pula dengan setiap modul praktikum juga menuliskan daftar pustaka yang digunakan untuk kegiatan praktikum laboratorium.

Jika perpustakaan tidak mengevaluasi semua daftar pustaka yang dituliskan dalam silabus mata kuliah itu, benar-benar dimiliki oleh perpustakaan atau tidak, maka bisa dikatakan bahwa pengadaan koleksi perpustakaan hanya berdasarkan usulan perpustakaan. Usulan ini tidak melihat kebutuhan pemustaka. Hal ini berakibat bahwa koleksi perpustakaan tidak relevan dengan kebutuhan pemustaka. Pada prinsipnya penyusunan silabus sudah sesuai dengan visi, misi, dan tujuan dari lembaga/ institusi, sehingga daftar pustaka yang disajikan juga mengarah ke sana. Dengan tidak digunakannya silabus mata kuliah sebagai alat bantu seleksi berdampak terhadap relevansi kebutuhan civitas akademika.

2. Dampaknya bagi dosen yaitu mereka tidak mengetahui apakah sumber referensi yang dituliskan dalam silabus itu disediakan oleh perpustakaan atau tidak. Selain itu, perpustakaan juga tidak akan tahu apakah sumber referensi tersebut masih up to date, mudah cara memperolehnya, atau sebaliknya.

3. Jika perpustakaan menggunakan silabus sebagai alat seleksi, maka perpustakaan akan mampu menginformasikan sumber referensi yang sudah dimiliki perpustakaan yang relevan dengan kebutuhan dosen dan mahasiswa dalam silabus tersebut.

4. Apabila daftar koleksi yang dituliskan di silabus susah diperoleh, maka bisa dicarikan alternatif cara perolehan, atau dengan mengganti judul dengan subjek yang sama, yang tujuannya adalah menyediakan koleksi relevan bagi pemustaka.

5. Dampak jangka panjangnya yaitu, jika koleksi tidak relevan dengan kebutuhan pemustaka, maka sedikit demi sedikit perpustakaan akan ditinggalkan oleh pemustaka karena tidak mampu memenuhi kebutuhan pemustakanya.

\section{Cara Mengatasi Kesenjangan Penggunaan Alat bantu Seleksi di Perpustakaan STIKES 'Aisyiyah Yogyakarta}

Ada beberapa cara yang dapat dilakukan untuk mengatasi kesenjangan penggunaan alat bantu seleksi di Perpustakaan STIKES 'Aisyiyah Yogyakarta antara lain sebagai berikut ini.

1. Perpustakaan bekerja sama dengan pada dosen atau pihak administrasi akademik yang bertugas mengumpulkan silabus semua mata kuliah dengan cara meminjam atau memfoto kopi silabus tersebut untuk dicocokkan dengan koleksi yang ada di perpustakaan.

2. Apabila hasil pengecekan menemukan bahwa ada daftar pustaka yang dicantumkan dalam silabus, namun tidak dimiliki oleh perpustakaan, maka perpustakaan segera membuat rencana pengadaannya. Caranya bisa dilakukan dengan : membeli (jika diperjualbelikan), memfoto kopi kepunyaan dosen yang bersangkutan (jika koleksi tersebut sulit ditemukan di pasaran), copy file, dan lain-lain.

3. Apabila hasil pengecekan menemukan bahwa daftar pustaka dalam silabus tersebut sulit ditemukan dan dosen yang bersangkutan atau dosen lain tidak memilikinya, maka mengusulkan dan menginformasikan koleksi dengan judul sejenis sebagai penggantinya kepada dosen yang bersangkutan.

4. Apabila hasil pengecekan menemukan bahwa daftar pustaka dalam silabus tersebut tahunnnya lama dan kurang up to date, maka perpustakaan mengusulkan dan menginformasikan koleksi dengan judul yang sama atau sejenis dengan tahun lebih baru sebagai penggantinya kepada dosen yang bersangkutan.

5. Perpustakaan juga harus bersinergi dengan prodi atau dosen tentang berbagai e-resources yang bisa diakses gratis agar diinformasikan kepada mahasiswa untuk dimanfaatkannya. Meskipun perpustakaan sudah sedemikian rupa mempublikasikan hal itu, dirasa lebih efektif jika dilengkapi dengan bantuan dosen kepada mahasiswa, 
termasuk menuliskan dalam silabus mata kuliahnya.

\section{Simpulan}

1. Penggunaan alat bantu seleksi di Perpustakaan STIKES 'Aisyiyah Yogyakarta bervariasi, namun masih terdapat kesenjangan antara penggunaan publisher announcement dengan bibliografi dan silabus mata kuliah.

2. Alasan yang menyebabkan penggunaan jenis alat bantu seleksi tertentu dalam pengadaan koleksi di Perpustakaan STIKES 'Aisyiyah Yogyakarta karena alat tersebut dianggap mudah, cepat, sesuai dengan tujuan pengembangan koleksi, sumber informasi elektronik mahal, dan perpustakaan tidak bisa menemukan sumber aslinya.

3. Alasan yang menyebabkan tidak digunakannya jenis alat bantu seleksi tertentu dalam pengadaan koleksi di Perpustakaan STIKES 'Aisyiyah Yogyakarta karena belum ada kerja sama dengan bidang akademik untuk menggunakan silabus mata kuliah sebagai alat seleksi dan tidak pernah diterimanya bibliografi dari pihak luar, dan jarangnya resensi buku kesehatan yang berbahasa Indonesia yang dimuat di media.

\section{Saran}

1. Kesenjangan penggunaan alat bantu seleksi dalam pengembangan koleksi di Perpustakaan STIKES 'Aisyiyah Yogyakarta sebaiknya dilakukan dengan penggunaan silabus mata kuliah sebagai alat bantu yang sangat efektif dan akan memberikan dampak langsung untuk mewujudkan koleksi yang relevan dengan kebutuhan pengguna.

2. Penggunaan silabus mata kuliah sebagai alat bantu seleksi, sebaiknya digunakan setiap semester untuk mengetahui perkembangan referensi yang digunakan oleh dosen dan mahasiswa dalam perkuliahan, dan ditujukan untuk semua program studi yang ada, serta ada tindak lanjutnya.

3. Perpustakaan STIKES 'Aisyiyah Yogyakarta sebaiknya mengirimkan surat permohonan daftar bibliografi yang diterbitkan oleh perpustakaan daerah dan Perpustakaan Nasional, sebagai tambahan alat seleksi koleksi sebagai salah satu solusi menghilangkan kesenjangan yang ada.

\section{Daftar Pustaka}

Arikunto, Suharsimi. 1998. Dasar-dasar Evaluasi Pendidikan. Yogyakarta: Bina Aksara.

Bryson, Jo. 1990. Effective Lirary and Information Centre Management. England: Gower Publishing Comany Limited.

Depdiknas RI, Dirjend Pendidikan Tinggi, 2004. Buku Pedoman Perpustakaan Perguruan Tinggi. Edisi ketiga. Jakarta: Depdiknas RI.

Echols, John M, dan Hasan Shadily. 1996. Kamus Inggris-Indonesia. Jakarta: Gramedia Pustaka Utama.

Evans, G Edward, Sheila S. Intner, and Jean Weihs. 2011. Introduction to Technical Services. Eight Edition. California: ABCCLIO, LLC.

Johnson, Peggy. 2009. Fundamentals of Collection Development and Management. USA: American Library Association.

Juliyanti, Poppy. 2002. Pengembangan Koleksi di Perpustakaan SMUN 68 Jakarta dalam Rangka Menunjang Kegiatan Belajar Mengajar. Skripsi. Jakarta: Fakulatas Sastra UI.

Purnomo, Jamu Saptari. 2006. Temu Kembali Biliografi dengan Bahasa Alami pada Field Judul Subjek (Studi Efektifitas Katalog Induk Terpasang Universitas Gadjah Mada) Berkala IImu Perpustakaan dan Informasi . Vol. III, No. 1 Yogyakarta: Universitas Gadjah Mada.

Qalyubi, Syihabuddin, dkk. 2003. DasarDasar IImu Perpustakaan dan Informasi. Yogyakarta: Jurusan IImu Perpustakaan dan Informasi, Fakultas Adab UIN Sunan Kalijaga.

Rambe, Abrar Rahmana. 2010. Relevansi Bahan Perpustakaan terhadap Kebutuhan Informasi Pengguna pada Politeknik Negeri Medan. Skripsi. Medan: Perpustakaan Universitas Sumatera Utara.

Stueart, Robert D and Barbara B. Moran. Library and Information Center Management. Fourth Edition. Colorado: Library Unlimited. 